\title{
How the Libyan Context can Shape Corporate Social Responsibility Disclosure in Libya Nagib Salem Mohammed Bayoud*
}

Department of Accounting \& Management, University of Tripoli, Libya

\begin{abstract}
This research has showed the relationship between the Libyan context regarding to sociocultural context, political context and economic context with corporate social responsibility disclosure (CSRD). The research has been used the literature review related this topic by books, papers, and master degree and PhD research. This research has covered the stage between 1970 until 2010. The results of this research revealed that the sociocultural context, political context and economic context can influence corporate social responsibility disclosure (CSRD) in Libya.
\end{abstract}

Keywords: Corporate social responsibility disclosure; Sociocultural context; Political context; Economic context

\section{Introduction}

Corporate social responsibility (CSR) and disclosure has become an important issue in the business world, because of some major corporate ethical disasters regarding the environment, human resources, and the community. In addition, there has been a growing demand for public firms to voluntarily disclose their CSR activities in the annual reports sent to stakeholders such as customers, suppliers, employees, investors, and activist organisations. The World Business Council for Sustainable Development defined CSR as the continuing commitment by business to behave ethically and contribute to economic development while improving that quality of life of the workforce and their families as well as of the local community and society at large.

In addition, corporate social responsibility disclosure (CSRD) is an extension of the financial disclosure system, which reflects the wider anticipation of society concerning the role of the business community in the economy. Furthermore, CSRD has an impact on companies in terms of financial performance, employee commitment, and corporate reputation. As a result, many studies in Australia, the United States, and the United Kingdom have focused on defining the relationship between CSRD and organisational performance. Although they have found the relationship between CSRD and organisational performance to be positive, other studies have found negative results, or a mixed relationship. In developing countries, despite growing concern for CSRD in various industries, only a few studies have focused on the impacts of CSR on organisational performance [1]. For example, Rettab et al (2009) found the relationship between CSR and organisational performance to be positive.

The research was undertaken in Libya, because Libya has an important standing in the world economy and uniqueness "a different political and economic system". Moreover, it is a particularly interesting country, as socialist and Islamic factors have impacted on the nature of CSRD. As a result, the level of CSRD has increased in Libya since 2000 due to pressures from stakeholders for information which may influence organisational performance for Libyan companies.

This research is organised into two sections. The first section includes the Libyan context which contains sociocultural context, political context and economic context. The final section shows the research conclusion.

\section{The Libyan Context}

A number of environmental factors influence the level and quality of business disclosures and of CSRDs in particular. The factors include social, cultural, political, economic, and legal factors, the last of which plays an important role in identifying levels of corporate disclosure.

\section{Sociocultural context}

Culture encompasses social, political, and other factors such as religion that can affect individuals' behaviours [2]. Aghila [3] explains that language and religion are considered vital cultural factors in Arabic countries, in particular Libya, which means these factors have a significant impact on the attitudes and behaviour of people.

Language: The official language in Libya is Arabic, although English is in common use, particularly among educated classes, in tourist areas, and in international business centres. Italian is the third most commonly used language due to the Italian colonization. Libya's private education system has ensured the ongoing use of English. In addition, some Libyan company (public and private) websites use English and Arabic. However, all Libyan companies prepare their annual reports in Arabic, as required by law. Nevertheless, a few Libyan companies (public and private) issue their annual reports in Arabic and English.

Religion: Religion is one of the most important aspects of Libyan society as most Libyans are religious. Religion has thus shaped the country's cultural background. Although all native Libyans are Muslim, more than one million foreigners live in Libya and most of them belong to various Christian denominations or Indo-Chinese religions [4]. There are churches and other places of worship for most of these religious groups.

The Libyan Constitution of September 11, 1969, declares in article 1 that Islam is the official state religion. Islamic values are practiced and

\footnotetext{
*Corresponding author: Nagib Salem Mohammed Bayoud, Department of Accounting \& Management, University of Tripoli, Libya, E-mail: bayoudns@gmail.com

Received march 01, 2013; Accepted May 16, 2013; Published June 11, 2013

Citation: Mohammed Bayoud NS (2013) How the Libyan Context can Shape Corporate Social Responsibility Disclosure in Libya. J Account Mark 2: 105. doi: 10.4172/2168-9601.1000105

Copyright: (C) 2013 Mohammed Bayoud NS. This is an open-access article distributed under the terms of the Creative Commons Attribution License, which permits unrestricted use, distribution, and reproduction in any medium, provided the original author and source are credited.
} 
confirmed in numerous state ceremonies. In November 1973, a new code of law was established that emphasises Islam Sharia in all aspects of Libyan law.

Islam is one of the most significant drivers behind the increase in CSR activities in Libya. Islam is the main factor that leads and regulates the attitudes and behaviour of Arabic societies. Islamic societies are varied in terms of their CSR practices and understandings of CSRD. As such Libya is a particularly interesting country, as societal and Islamic factors have influenced the nature of disclosure. According to Pratten and Mashat (2009), "the Islamic influence adds further demands on legislation, behaviour, and industrial change." According to Ali [5], Islam organises the social life within the family and in other social organisations and supports their endurance and influence.

Geography, Population, Demographics: Located in North Africa, Libya is considered one of the most important Arabic countries. Libya not only links eastern and western Africa and Southern Europe and Africa. Libya is bounded by Egypt to the east, the Mediterranean Sea to the north, Tunisia and Algeria to the west, Sudan to the southeast, and Niger and Chad to the south; It is the fourth largest state in Africa. It also has a Mediterranean coastline of almost 2,000 km (1,250 miles). Although the land of Libya is $94.73 \%$ desert, $3.94 \%$ agricultural, and $0.29 \%$ forests\%, the total area of Libya is approximately $1,775,500$ $\mathrm{km}^{2}$. Otman and Karlberg (2007) indicate that Libya consists of three regions: Tripoli in the northwest, Cyrenaica in the east, and Fezzan in the southwest.

In 2006, Libya had a population of nearly 575 million, made up of approximately $51 \%$ male and $49 \%$ female (Table 1). According to available data, approximately 4 million people live in coastal cities of Benghazi, Misurata, Zawia, and Derna, but especially in the capital city of Tripoli, where about 2.5 million people live.. At 3.5 percent, Libya has one of the highest population growth rates in the world. Furthermore, Libya has one of the highest urbanization rates in the world, with almost 86 percent of its population living in urban areas. About 50 percent of Libya's population is under 20 years old [6].

The family is considered an essential unit in Libyan society, a family and its members are assigned to a hierarchical order based on age and generation. El Fathaly (cited in Ahmad \& Gao [7]) states that the father, grandfather, and oldest son represent leadership and authority in the Libyan family. Islam and Arabic custom support the role of the family in Libyan society and its status, which is based on the afore-mentioned hierarchy [8]. Bjerke and Al-Meer [8] note that, in Libya, while leaders hold authority at the community level, fathers hold authority at the family level.

The organisation of Libyan society is similar to that of other Arabic countries and is divided into extended families, villages, clans, and tribes. Agnaia [9] states that these social units play a major role in people's relationships and community life. More specifically, because one's loyalty to the law and one's profession is occasionally weaker than one's loyalty to one's village, tribe, clan, and family, it is more common for career promotions and business connections to be obtained through family contacts and personal relationships than through one's academic qualifications or practical experience [9].

International accounting literature has focused on the impact of society and culture on accounting practice in general and in particular on corporate disclosure [2]. Numerous studies investigate the effects of society and culture on the structure of business and accounting, and in particular on corporate disclosures [10-14]. These studies arrive at the following conclusion: society and culture are considered among the most important factors affecting business performance and accounting.

Clearly, public organisations should contribute and disclose their activities that lead to the well-being of society. Thus, this argument might support the stakeholder theory, which claims that in a society concerned with social issues, user groups (i.e., stakeholders) may use more power, possess greater legitimacy, and have their claims viewed with greater urgency. In this vein, just as societal values can affect managerial values, so might decision makers (such as managers) in societies with a strong interest in or concern with social issues, be more aware of stakeholder claims and therefore place more importance on them.

\section{Political context}

The political system in Libya's began September 1, 1969, when a group of army officers called the Revolutionary Command Council (RCC) took power. The principles of the RCC were Freedom, Socialism, and Unity. The RCC renamed Libya the Libyan Arab Republic. As the leader of the RCC, Muammar Gaddafi became the Prime Minister and the Defence Minister Gaddafi. In the 1970s, Gaddafi presented his Green Book, which presented in three parts (political, economic, and social programs), his Third Universal Theory. Moreover, the Third Universal Theory was presented as representing the Libyan policies until Feb 2011.

Gaddafi presented Libya's new political system in 1977, which

\begin{tabular}{|c|c|c|c|c|c|c|}
\hline \multirow{2}{*}{ Population } & \multirow{2}{*}{ Ages } & \multicolumn{2}{|c|}{ Number in population } & \multicolumn{3}{|c|}{ Percentage of total population } \\
\cline { 3 - 7 } & & Male & Female & Total & Male & Female \\
\hline 1995 & Total & 2231079 & 2158660 & 4389739 & 50.82 & 49.18 \\
\hline 2006 & Total & 2695145 & 2628846 & 5323991 & 50.62 \\
\hline
\end{tabular}

Source: Libyan Higher Committee for Statistics and Census 2006 (Otman \& Karlberg 2007).

Table 1: Distribution of Libyan Population, 2005 and 2006.

\begin{tabular}{|c|c|c|c|c|c|c|}
\hline & 1967 & 1975 & 1980 & 1985 & 1990 & 1997 \\
\hline GDP (LD million): & 748 & 3,674 & 10,554 & 7,852 & 7,750 & 12,976 \\
\hline Oil sector & 403 & 1,961 & 6,526 & 3,500 & 2,741 & 2,978 \\
\hline Non-oil sector & 345 & 1,713 & 4,028 & 4,352 & 5,009 & 9,998 \\
\hline Per Capita (LD million) & 430 & 1,369 & 3,252 & 2,140 & 1,600 & 2,426 \\
\hline Per Capita (\$) & 1,250 & 4,624 & 10,985 & 7,228 & 4,320 & 6,064 \\
\hline
\end{tabular}

LD = Libyan currency (Libyan Dinar)

Source: The Libyan Secretary of Planning (1998), Economical and Social Development Achievements in 28 years; The Secretary of Planning (1997), Economic and Social Indicators (1962-1996). 
introduced five major reforms leading to basic changes in the country's structure. This system was then accepted in an extraordinary session of the General People's Congress G.P.C. under Muammar Gaddafi's chairmanship. The five reforms were (1) the official name of Libya became the Socialist People's Libyan Arab Jamahiriya (SPLAJ), (2) the Holy Book of Islam became the official social code, (3) the authority is for the all Libyan people and no one else as this system represented the basis of the political system in the SPLAJ, (4) the People's Congresses, People's Committees, Syndicates, Unions, Professional Associations, and the G.P.C became functions that define and maintain law and order and through which the Libyan people exercised their power (Figure 1).

Figure 1 show that Libyan people debate and made decisions through the Basic People's Congress. The Basic People's Congress collected and reformatted the people's decisions, then passed them on to the General People's Congress for consideration and implementation as national policy. There were at least 1,500 Basic People's Congresses in Libya. Each congress has its own budget and legislative and executive powers. They also elected a secretariat to represent them in the General People's Congress. Twice a year the General People Congress met to pass resolutions, adopted laws and decrees, and nominate ministers to the General People's Committees (or the cabinet). Finally, the responsibility of every Libyan citizen was homeland defence and all citizens received arms and general military training. Law defines the methods of training military institutions and the general military. This system finished in the SPLAJ.

Libya's political system affects the behavior of organizations and the people in certain ways. It has been argued that Libya's political and governmental stability affect accounting in numerous ways. Alhashim and Arpan 1992 (Saleh 2001) indicate that in societies where the government sets accounting rules, then when major changes happen in the people governing, these changes may lead to changes in the accounting procedures of the country. The degree of political rights and civil liberties evident in a country's political and civil structure is based on the degree of political and civil freedom in that country. As a result of violations of political rights and civil liberties associated with certain forms of political structures, the restriction of political and civil freedoms are likely to pose obstacles to full and fair disclosure. In light of this, a number of studies have examined the relationship between political systems and accounting practices. For example, Goodrich (1986) found a significant relationship between accounting practices and political systems, "Political factors, like political system types and international organizational membership, are significantly linked to the accounting groups." Williams (1999) also found a positive correlation between the degree of social and environmental information in companies' annual reports and civil repression and the level of political freedom for Asia-Pacific companies.

\section{Economic and business context}

Libya is a rich developing country that is just beginning to change to a market-based economy. It is also attempting to rapidly move towards economic growth (UNDP 2007). Briefly stated, the history of economic development in Libya has occurred as follows: Agriculture was considered as the primary sector of the Libyan economy before the discovery of oil in 1959. Benjamin Higgins, who worked as an economic adviser to Libya in the twentieth century, described the Libyan economy between 1950 and 1963 as a deficit economy.

Higgins (1959) indicated in his book that Libya's great merit as a case study is as a prototype of a poor country. We need not construct abstract models of an economy where the bulk of the people live on a subsistence level, where per capita income is well below US\$ 50 per year, where there are no sources of power and no mineral resources, where agriculture expansion is severely limited by climatic conditions, where capital formation is zero or less, where there is no skilled labour supply and no indigenous entrepreneurship ... Libya is at the bottom of the range in income and resources and provides a reference point for comparison with all other countries.

The International Bank for Reconstruction and Development (IBRD) (1960) also mentioned that as a result of the deficit of the Italian economy in their period of colonization of Libya, this situation led to the neglect of Libyan education and technical skill and excluded the Libyan employees from any significant careers, in particular in the administration of Libya, which did not allow them to improve

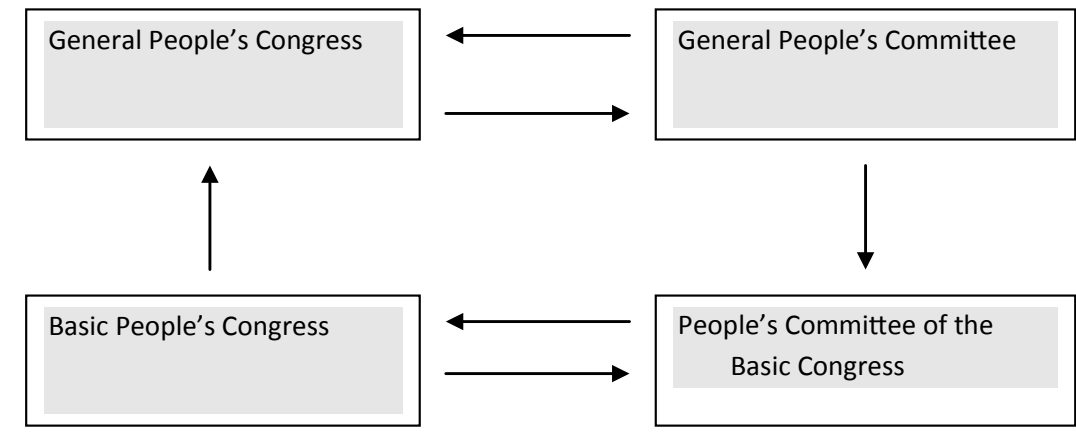

Direction of Control, Choice and Control, Accountability
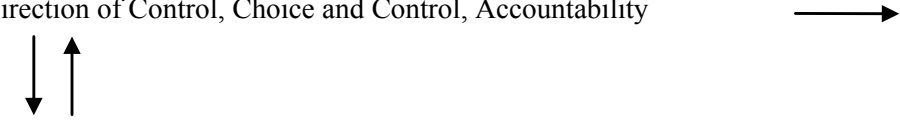

Source: Adapted from Bait-Elmal [15]

Figure 1: The Structure of People's Congresses and People's Committee. 
their skills and experience. IBRD (1960) emphasized that as a result of these causes, Libya has focused on the training of Libyans to fill foreign administrative and technical positions, and this process is still the trickiest of all the problems related to the Libyan economic development. At this stage, the Libyan economy was characterized by low levels of literacy and health, chronic trade deficits, low levels of consumption and domestic production, and underexploited natural resources. Therefore, the Economic and Social Council (ESC) of the United Nations issued a decree at the beginning of 1950 to treat these problems by supplying foreign aid to promote the Libyan economy.

The discovery of oil in 1955 led to the end of foreign aid and major modifications in all aspects of Libyan life. In just five years, Libya changed from a poor country to one of the richest country in the world. Bait El-mal [15] indicates that the discovery of oil attracted many foreign oil companies to Libya; in particular USA and UK oil companies. Western advisers in Libya thus designed Libyan petroleum laws in 1955 to encourage foreign companies to explore, carry out oil development operations, and release oil from the Libyan Desert. In addition, by 1969 some 2,000 international companies from non-oil sectors registered manufacturing concerns in Libya. Some Libyans worked in these companies, but foreigners built and controlled the administrations of these companies.

A number of changes occurred in the Libyan economy after September 1, 1969. The leaders of the 1969 revolution took steps to restructure the economy. They were observed that the benefits accruing from oil heavily favoured foreign and international companies rather than Libya, and hence there was a need to nationalize the control of Libyan oil. Kilani (1988) stated that this stage witnessed the rapid disappearance of the private sector due to the revolutionaries' opposition to capitalism; however, this stage was also characterized by the rapid development of the and non-oil revenues (Table 2) to develop the economy. Libyan economy, the formation of an extensive range of public organisations, and the establishment of publicly owned organisations. In this respect, the Libyan government prepared to employ its three plans by using oil revenues.

The short-term plans specified finance infrastructure projects, such as roads, water, and hospitals. The medium-term plans involved the development of economic sectors, such as agriculture, services, and industry. The long-term plans aimed to expand and convert the Libyan economy from that of a developing to a developed economy. El- Jehaimi (1987) notes that prior plans also aimed to focus on agriculture and industry more than other sectors, to reduce agricultural and industrial imports from foreign countries, and to achieve self-sufficiency in the agricultural and industrial sectors, to redirect revenues from the oil sector to finance the requirements of the other sectors, and to limit foreign participation and focus on the role of national workers in the development effort.

The new economic system was based on the "Third Universal Theory" from the Green Book, written by Muammar Gaddafi. The Green Book is titled The Third Universal Theory. Gaddafi claimed this theory resolved Libya's economic problems by giving workers the right to benefit from the products being produced, whether as a public or private establishment; whereas, all prior theories attempted to resolve the economic problems from either the perspective of ownership of the means of production or from that of the wages for production. These prior attempts failed due to being based on "a wage system."

In 1970, Gaddafi's reforms gave Libyan workers the right to manage their own organisations. People's Committees (PC) were chosen by workers in most Libyan companies. The economic reforms stemming from the Green Book meant workers were not wage workers but partners in managing Libyan companies. The Green Book also stated that

If we analyse the economic factors of production from ancient times till now we always find that they are composed of these essentials: raw materials, an instrument of production and a producer. The natural rule of equality is that each of the factors has a share in this production, for if any of them is withdrawn, there will be no production. Each factor has an essential role in the process of production and without it production comes to a halt. As long as each factor is essential and fundamental, they are all equal in their essential character within the process of production. Therefore they all should be equal in their right to what is produced. The encroachment of one factor on another is opposed to the natural rule of equality, and is an attack on the right of others. Each factor, then, has a share regardless of the number of factors. If we find a process of production, which can be performed by only two factors, each factor shall have half of the production. If it is carried out by three factors, each shall have a third of the production.

The People Committee's are responsible for managing organisations in Libya. Each employee in a Libyan company can be a member of the People's Committee, which includes the head of the company. Thus, the top of the hierarchical structure can be managed by employees, who contribute to decision making. This process may lead to poor decisions, however, because most employees have inadequate experience or educational qualifications. This means that society's values stem from the economic activities and decisions rendered by all Libyan organisations. All Libyan organisations, thus should again study the issues related to employee rights and protections as well as their impacts on Libyan organisations. In addition, employees in Libya are dealt with as partners, not as wage-earners. However, public organisations are more focused on providing basic services and goods to citizens, rather than focusing on maximizing profits.

Economic development plays an important role in the development of accounting practices, particularly in reporting and disclosure. Economic development can directly and indirectly influence corporate disclosure in a country. Williams(1999) asserts that one of the most important factors that received wide attention recently is the level of economic development and its impact on accounting. Economic development in a country encompasses economic growth and structures and social changes. To evaluate the performance of every organisation in terms of productivity and efficiency, the three previous factors (economic growth and structures as well as social changes) need to use financial and reporting tools.

The role of accounting in any country affects economic development, "accounting information has the potential to play a very important part in many of the debates on the issues of affecting economic development". All companies and government authorities need to receive financial information within relevant certain time frame for a number of reasons, including to efficiently allocate and use economic resources, to control and safeguard assets, to price services and goods, to value assets, and to measure and evaluate performance. Novin and Baker (1990) asserted that it is difficult and complicated for all companies and government authorities to dispense reliable and sufficient accounting information within the relevant time, to allow effective control and management.

Additionally, a number of studies have examined the relationship between accounting and economic development. This relationship 
Citation: Mohammed Bayoud NS (2013) How the Libyan Context can Shape Corporate Social Responsibility Disclosure in Libya. J Account Mark 2: 105. doi: $10.4172 / 2168-9601.1000105$

Page 5 of 5

is observed due to the major role accounting plays in providing information on macro- and micro-economic activities to make effective decisions at various levels. The accounting function plays a stewardship and reporting role and a budgeting and forecasting role at the micro level, and also encompasses the creation of adequate information for planning and administering purposes, and for controlling the economy and demanding accountability at the macro level. Clearly, there is a significant and strong interplay between the macro and micro levels of accounting, on the one hand, and the macro and micro levels of the economy, on the other. In this regard, micro data are used for macro accounting, while macro and micro data use macro accounting for assessing and decision making. More specifically, the macro accounting framework combines the accounting and the economic frameworks. Although micro accounting forms a significant and effective part of the macro accounting database, it is concerned with measuring and reporting results of economic activities of micro units in an economy. Both micro and macro accounting and economic frameworks, therefore, should be used to improve information quality.

\section{The Research Conclusion}

This research has showed the Libyan context and its effect on corporate social responsibility disclosure (CSRD). It can be seen that Libya has a unique economic, political, and social system. It is based on the "Third Universal Theory" of the Green Book and Islamic instructions. The Libyan economy is neither classical political economy nor a bourgeois political economy.

Additionally, this research has described the social and environmental concerns in Libya. It has revealed that changes in the Libyan social environment have influenced corporate social responsibility (CSR) and corporate social responsibility disclosure (CSRD). It has also showed the importance of CSRD and stakeholders' pressure in particular after the establishment of a stock market in Libya.

The future research can cover the following points in the Libyan context: the relationship between regulatory system and corporate social responsibility disclosure. How education system can shape corporate social responsibility disclosure.

\section{References}

1. Kang $\mathrm{KH}$, Lee S, Huh C (2010) Impacts of positive and negative corporate social responsibility activities on company performance in the hospitality industry. International Journal of Hospitality Management 29: 72-82.

2. Hamid S, Craig R, Clarke F (1993) Religion: a confounding cultural element in the international harmonization of accounting? Abacus 29: 131-48.

3. Aghila EA (2000) Job satisfaction and work commitment in the context of Libya The Manchester Metropolitan University, Manchester, UK.

4. Attir Moa, Al-Azzabi K (2004) The Libyan Jamahiriya: Country, People, Socia and Political Development. Doing business with Libya, Kogan Page Ltd London, UK.

5. Ali A (1996) Organisational development in the Arab World. Journal of Management Development 15: 4-21.

6. Arab Banking Corporation: ABC (2001) The Arab Economic: Structure and Outlook, Manama, Bahrain Kingdom.

7. Ahmad Na, Gao S (2004) Changes, Problems and Challenges of Accounting Education in Libya. Accounting Education: International Journal 13: 365-90.

8. Bjerke B, Al-Meer A (1993) Culture's consequences: management in Saud Arabia. Leadership \& Organization Development Journal 14: 30-5.

9. Agnaia AA (1997) Management Training and Development within its Environment: the Case of Libyan Industrial Companies. Journal of European Industrial Training 21: 117-23.

10. Archambault JJ, Archambault ME (2003) A multinational test of determinants of corporate disclosure. The International Journal of Accounting 38: 173-94.

11. Cravens KS, Oliver EG (2000) The Influence of Culture on Pension Plans. The International Journal of Accounting 35: 521-37.

12. Doupnik TS, Salter SB (1995) External Environment, Culture, and Accounting Practice: A Preliminary Test of a General Model of International Accounting Development. International Journal of Accounting 30: 189-207.

13. Gray SJ (1988) Towards a Theory of Cultural Influence on The Development of Accounting Systems Internationally. Abacus 24: 1-15.

14. Hofstede GHa, Bond MH (1988) The Confucius Connection: From Cultural Roots to Economic Growth. Organisational Dynamics 16: 5-21.

15. Bait-Elmal A (2000) The Role of Management Control Systems in Libyan Organizations: A Libyan Development Policy Case Study with Special Reference to the Industrial Sector. Manchester Metropolitan University, Manchester, UK. 